\title{
CDKN3 wt Allele
}

National Cancer Institute

\section{Source}

National Cancer Institute. CDKN3 wt Allele. NCI Thesaurus. Code C49514.

Human CDKN3 wild-type allele is located within $14 q 22$ and is approximately $23 \mathrm{~kb}$ in length. This allele, which encodes cyclin-dependent kinase inhibitor 3 protein, may play a role in cell cycle regulation. Defects in CDKN3 allele have been identified in patients with hepatocellular carcinoma (HCC) and the allele is deleted, mutated, or overexpressed in several kinds of cancers. 